\title{
New Combinations within North American Schoenoplectus smithii and S. purshianus (sect. Actaeogeton, Cyperaceae) and Comparison with Eastern Asian Allies
}

\author{
S. Galen Smith \\ Department of Biological Sciences, University of Wisconsin-Whitewater, Whitewater, \\ Wisconsin 53190, U.S.A. sgsmith2@facstaff.wisc.edu \\ Eisuke Hayasaka \\ Botanical Garden, Graduate School of Science, Tohoku University, Sendai, 980-0862 Japan. \\ hayasaka@biology.tohoku.ac.jp
}

Abstract. The new combinations Schoenoplectus purshianus (Fernald) M. T. Strong var. williamsii (Fernald) S. G. Smith, S. smithii (A. Gray) Soják var. setosus (Fernald) S. G. Smith, and S. smithii var. levisetus (Fassett) S. G. Smith are made. Diagnostic features, mainly from spikelet dimensions, perianth bristles, and achenes, are provided that distinguish the eastern North American S. smithii and $S$. purshianus, and the eastern Asian and Pacific island S. hotarui (Ohwi) Holub, S. juncoides (Roxburgh) Palla, and S. komarovii (Roshevitz) Soják, all five of which have been confused with each other. A description of Schoenoplectus sect. Actaeogeton (Reichenbach) J. Raynal is provided based mostly on North American and eastern Asian species.

Key words: Asia, Cyperaceae, North America, Schoenoplectus, Schoenoplectus sect. Actaeogeton.

This paper derives from the senior author's work on his treatment of Schoenoplectus (Reichenbach) Palla for the upcoming volume 23, Cyperaceae, of the Flora of North America (FNA), during which he studied numerous herbarium specimens from about 52 herbaria (Smith, 1995), as well as from the junior author's ongoing work toward a monograph of Schoenoplectus, during which he studied numerous herbarium specimens from the herbaria listed in the acknowledgments.

Scirpus L. s.l. has been segregated worldwide in recent years based on embryo as well as vegetative and reproductive characters (Bruhl, 1995; Goetghebeur \& Simpson, 1991; Hayasaka \& Ohashi, 2000; Smith \& Hayasaka, 2001; Smith \& Yatskievych, 1996; Wilson, 1981). Nine segregate genera will be recognized for the upcoming Flora of North America: Amphiscirpus, Blysmus, Bolboschoenus, Isolepis, Oxycaryum, Schoenoplectus, Scirpus, Tricho- phorum, and Websteria. The largest of these in North America is Schoenoplectus with about 70 species worldwide and 17 in North America.

Schoenoplectus is diverse morphologically and has been divided into several infrageneric taxa (Oteng-Yeboah, 1974; Raynal, 1976; Smith \& Hayasaka, 2001). Smith and Hayasaka (2001) recognized and provided a key to four sections within Schoenoplectus: sect. Schoenoplectus, sect. Actaeogeton (Reichenbach) J. Raynal, sect. Malacogeton (Ohwi) S. G. Smith \& Hayasaka, and sect. Supini (Chermezon) J. Raynal.

Upon their transfer from Scirpus to Schoenoplectus, the infraspecific taxa of the two native North American species of Schoenoplectus sect. Actaeogeton, S. purshianus (Fernald) M. T. Strong and $S$. smithii (A. Gray) Soják, require new combinations. These species also have been confused with each other as well as with three species of eastern Asia and adjacent western Pacific islands (Koyama, 1958, 1962). In addition, the section Actaeogeton has never been clearly delineated. This paper addresses these nomenclatorial and taxonomic problems.

1. Schoenoplectus purshianus (Fernald) M. T. Strong, Novon 3: 202. 1993. Scirpus purshianus Fernald, Rhodora 44: 479. 1942. Scirpus debilis Pursh, Fl. Amer. Sept. 1: 55. 1814, non Scirpus debilis Lamarck, Illustr. 1: 141. 1791. Scirpus erectus Poiret var. debilis Camus, Fl. Gen. Indo-Chine 7: 136. 1912. TYPE: U.S.A. Pennsylvania: Muhlenberg Herbarium, "No. 65" and "m. 33" (lectotype, designated by Strong (1993: 203), PH, Herb. Muhl. sheet 345-74, photograph seen; isolectotype, $\mathrm{PH}$, Herb. Muhl. sheet 345-75, photograph seen).

Muhlenberg first published the name Scirpus de-

Novon 12: 106-111. 2002. 
bilis without a description in his 1813 catalog, and Pursh apparently appropriated Muhlenberg's earlier name. The lectotype and duplicate sheet may have been seen by Pursh (Merrill \& Hu, 1949), or the specimens may even have been collected by Pursh (C. E. Smith, 1962: 458). A. E. Schuyler and J. Macklin at PH have kindly provided us with photographs of the types and closely examined the specimens. On the lectotype sheet, "Scirpus debilis lupulinus Sm." is written on the label; "345-74" is at the bottom of the sheet. The annotation directly on the sheet reads "Scirpus purshianus Fern. Type of Scirpus debilis Pursh, AE Schuyler 1976"; this sheet bears 15 inflorescence-bearing culms, 3 of which are attached together at their bases, and 12 are without bases. A second sheet bears labels and annotations similar to those on the lectotype with "345-75" written at the bottom of the sheet, and the annotation on the sheet reads "Scirpus purshianus Fern. TYPE MATERIAL of Scirpus debilis Pursh, Fl. Am. Sept. 1: 55. 1813[1814]. AES 1976." It bears 14 culms with inflorescences, and is evidently part of the same collection as the lectotype. All culms on both sheets are very similar, and several bear achenes with attached bristles, which are typical of Schoenoplectus purshianus (A. E. Schuyler \& J. Macklin, pers. comm. 2001).

1a. Schoenoplectus purshianus var. purshianus

Perianth bristles 6, stout, tapered distally, about equaling achene, densely spinulose. Reported habitats: shores of inland ponds and ditches. Distributed throughout the range of the species in northeastern North America from Quebec to Georgia westward to Minnesota, eastern Missouri, and northern Louisiana.

1b. Schoenoplectus purshianus var. williamsii (Fernald) S. G. Smith, comb. nov. Basionym: Scirpus debilis Pursh var. williamsii Fernald, Rhodora 3: 252. 1901. Scirpus smithii A. Gray var. williamsii (Fernald) Beetle, Amer. J. Bot. 29: 655. Oct. 1942. Scirpus purshianus Fernald f. williamsii (Fernald) Fernald, Rhodora 44: 479. Dec. 1942. Scirpus juncoides Roxburgh var. williamsii (Fernald) T. Koyama, Canad. J. Bot. 40: 914. 1962. Schoenoplectus smithii (A. Gray) Soják subsp. williamsii (Fernald) Soják, Cas. Nár. Mus. Odd. Prir. 148: 194. 1980. TYPE: U.S.A. Massachusetts: sandy shore of Massapoag Lake, Sharon, 7 Sep. 1901, Plantae Exsiccatae Grayanae 26, E. F. Williams \& M. L. Fernald s.n. (holotype, $\mathrm{GH}$; isotypes, BRIT, CAS, GH, ILL, MO, NEBC, SAPS, UC, WTU).
The names Scirpus smithii A. Gray var. williamsii (Fernald) Beetle and Scirpus juncoides Roxburgh var. williamsii (Fernald) T. Koyama were misapplied by their authors to the entire species $S$. purshianus. Koyama (1963: 457) stated that his new combination Scirpus juncoides Roxburgh var. digynus (Böckler) T. Koyama has priority over Scirpus debilis var. williamsii. As Koyama referred to his 1962 paper, he apparently intended his new varietal combination to apply to the whole species $S$. purshianus. Böckler's type of the basionym Scirpus supinus L. [var.] digynus Böckler needs to be examined to determine the specific and varietal identity of Scirpus juncoides var. digynus (Böckler) T. Koyama.

Perianth bristles absent. Reported habitats: shores of lakes, reportedly with substantial waterlevel fluctuations. This variety is known only from the type locality in eastern Massachusetts, several counties in southwestern Michigan, one county in adjacent Indiana, and two counties in Wisconsin.

2. Schoenoplectus smithii (A. Gray) Soják, Cas. Nár. Mus. Odd. Prir. 141: 62. 1972, not Schoenoplectus smithii (A. Gray) J. Raynal, Adansonia, n.s., 16(4): 530. 1977. Scirpus smithii A. Gray, Manual ed. 5: 563. 1867. TYPE: U.S.A. New Jersey: in tidal mud on the N.J. shore of the Delaware below Red Bank opposite the River Schuylkill, July 1865, C. E. Smith s.n. (holotype, GH; isotype, PH).

\section{2a. Schoenoplectus smithii var. smithii}

Perianth bristles absent or rudimentary. Reported habitats: fresh-water tidal shores of rivers and inland shores with large fluctuations in water level. This variety is known from Quebec (St. Laurence River near Quebec City) to New Jersey westward to Minnesota.

2b. Schoenoplectus smithii var. setosus (Fernald) S. G. Smith, comb. nov. Basionym: Scirpus smithii A. Gray var. setosus Fernald, Rhodora 3: 252. 1901. Scirpus smithii A. Gray f. setosus (Fernald) Fernald, Rhodora 44: 479. 1942. TYPE: U.S.A. Illinois: Augusta, 1845, S. B. Mead s.n. (holotype, GH; isotypes, GH, NY, PH).

Perianth bristles 4 to 6 , equaling or slightly exceeding achene, densely spinulose. Chromosome number $n=19$ (Schuyler, 1972). Reported habitats: wet places with little fluctuation in water level such as mires and shores of small lakes or ponds. This variety is known from Quebec (near Quebec 
City) to Delaware and western North Carolina westward to Wisconsin and Minnesota. In Michigan, Wisconsin, and Minnesota it is much more common than S. smithii var. smithii.

2c. Schoenoplectus smithii var. levisetus (Fassett) S. G. Smith, comb. nov. Basionym: Scirpus smithii A. Gray var. levisetus Fassett, Rhodora 19: 42. 1921. Scirpus smithii A. Gray f. levisetus (Fassett) Fernald, Rhodora 44: 479. 1942. TYPE: U.S.A. Maine: tidal flats of the Cathance River at Bowdoinham and at its mouth in Merrymeeting Bay, 25 Aug.-2 Sep. 1920, N. C. Fassett s.n. (holotype, GH; isotype, NY).

Perianth bristles 1 to 3 (4), mostly much shorter than achene, mostly without spinules. Chromosome number $n=19$ (Schuyler, 1972). Habitat: restricted to fresh-water (or slightly brackish?) tidal muddy or rocky shores of rivers. This variety is very locally distributed but sometimes locally common (Schuyler, 1972). Smith has seen specimens from New Brunswick (Northumberland Co.), Quebec (Portneuf Co., near Quebec City), Connecticut (New Haven), Massachusetts (Middleton Co.), Maine (Penobscott and Sagadahoc Cos.), and Virginia (Fairfax Co.). It is known to be extirpated from Virginia (Strong, 1994).

Koyama (1962: 919) treated the eastern Asian Schoenoplectus komarovii (Roshevitz) Soják as Scirpus smithii var. leiocarpus (Komarov) T. Koyama, = Schoenoplectus smithii subsp. leiocarpus (Komarov) Soják, basionym Scirpus supinus L. var. leiocarpus Komarov (other synonyms and type given by Koyama, 1958, 1962). However, our herbarium observations and published descriptions (Koyama, 1958, 1962; Ohwi, 1965) indicate that, pending a revision of the $S$. juncoides complex, S. smithii var. leiocarpus should be treated as the distinct species $S$. komarovii following Ohwi (1965). Although S. komarovii is similar to $S$. smithii var. setosus in most characters, including those of perianth bristles and achene shape and surface, it differs from S. smithii in its smaller achenes and its frequently compound inflorescences (Table 1).

While Smith has not detected morphological differences between the varieties other than those of the perianth bristles as given above, in his opinion these five infraspecific taxa should be treated as varieties rather than forms because the perianth bristle differences appear to be correlated with habitat differences, and thus these taxa can be interpreted as ecotypic varieties and may be valuable ecological indicators. Also, form status implies that the morphological differences are completely trivial.

Schoenoplectus smithii var. setosus, S. smithii var. levisetus, and $S$. purshianus var. williamsii were first described with no mention of ecological differences except for S. smithii var. levisetus, for which Fassett (1921) found the fresh-water tidal habitat remarkable. When Fernald (1942: 483) reduced the varieties to forms he merely stated: "... their differences are in the presence or absence of perianth-bristles, or in the case of $S$. smithii, forma levisetus, the lack of retrorse barbs on the bristles." However, Schuyler (1972: 398-399) stated: "In both $S$. purshianus and $S$. smithii the presence or absence of barbed bristles appears to be correlated with the stability of the habitat. For example in eastern New York, New Jersey, eastern Pennsylvania and Delaware, S. smithii f. smithii is almost completely restricted to the specialized conditions of fresh inter-tidal zones of the Hudson, Raritan and Delaware Rivers while in the same area f. setosus occurs in and around lakes, ponds and quagmires.... Thus it appears that plants of S. smithii which lack barbed bristles are better adapted to the periodic fluctuations in water levels which are characteristic of the estuarine environment than are those which have barbed bristles.... S. smithii f. levisetus is common along the estuaries of the Kennebec River in Maine and the St. Lawrence River in Quebec." Ferren and Schuyler (1980) and Strong (1994) essentially repeated these statements for $S$. smithii var. smithii and S. smithii var. setosus and provided more detailed ecological information for S. smithii var. smithii.

The few data Smith have seen on herbarium labels support these reported habitat differences. For S. smithii var. smithii, in addition to coastal estuaries, reported habitats include protected beaches of the very large Lakes Huron, Erie, Cayuga (New York), Oneida (New York) and Champlain. In contrast, reported habitats for S. smithii var. setosus are "bog" pools and peaty quagmires, marsh edges, sandy or muddy lake and river shores, marshy shore of drying shallow seepage lake, recently scraped road through wet meadow near lake shore, floating muck in lake in center of bog, mill pond, and muck of small drying-up alkaline lake.

Schoenoplectus purshianus and S. smithii have been widely confused. Many specimens are misidentified, and some authors have treated S. purshianus and S. smithii as conspecific (Beetle, 1942; Gleason, 1963; Gleason \& Cronquist, 1963; Voss, 1972). Most published distributions are therefore erroneous, and the distributions given here are based almost entirely on specimens that the senior 


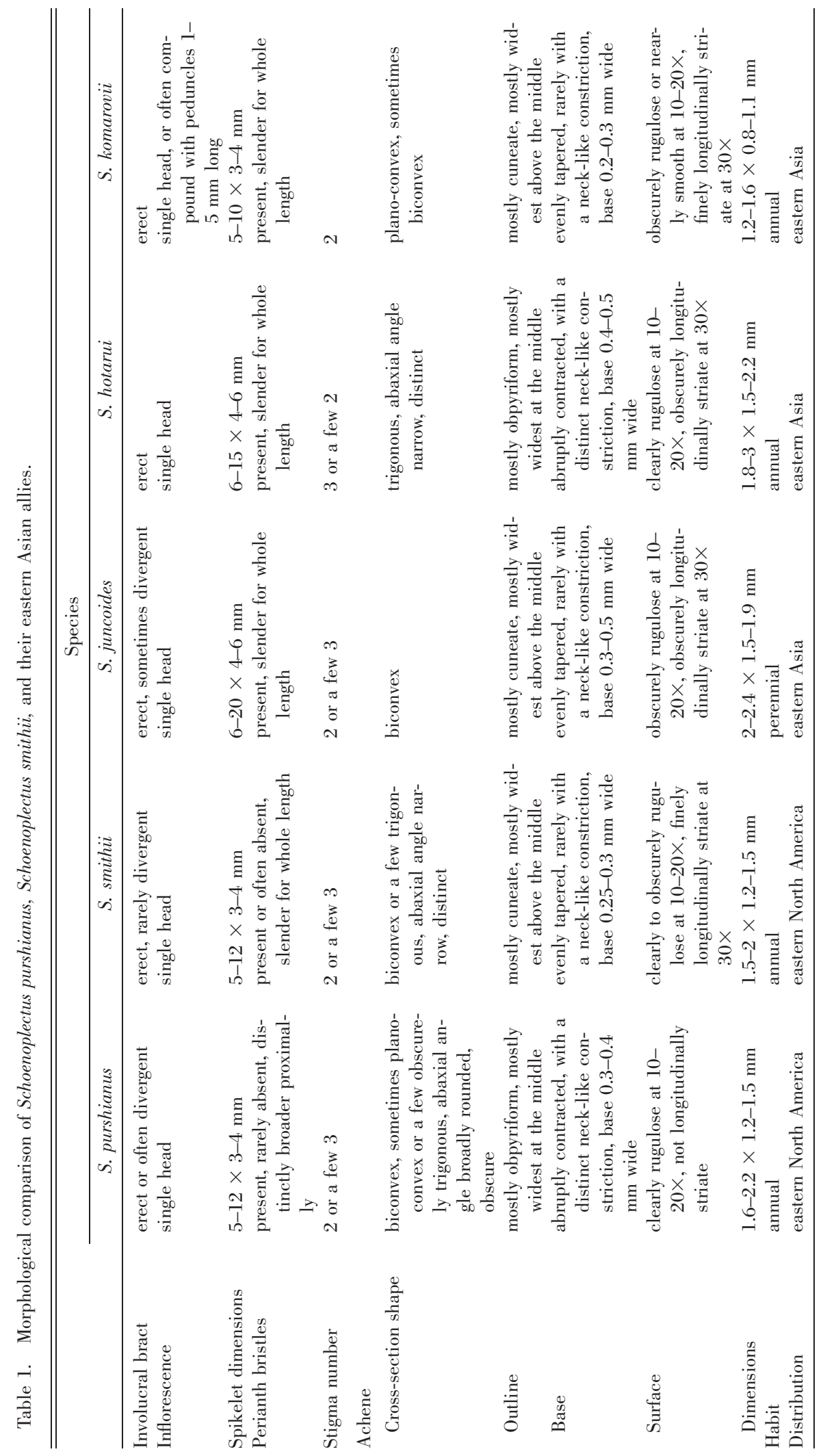


author has seen. The taxonomic confusion is due to the subtle nature of the diagnostic characteristics of achenes and perianth bristles as illustrated by Strong (1994), Blondeau et al. (1996), and in the upcoming volume 23 of the Flora of North America, and is summarized in Table 1 herein. Confusion is also caused by the presence in both species of plants with or without perianth bristles as well as plants with erect proximal involucral bracts. Plants without bristles may be identified to species using the differences in achene shape and surface sculpturing as given in Table 1 .

Our herbarium studies and the literature indicate that Schoenoplectus purshianus and S. smithii should be treated as distinct species restricted to eastern North America and distinct from their relatives, which are found in eastern Asia and the Pacific islands. Some authors, however, have treated S. purshianus and S. smithii as conspecific with eastern Asian species of the "S. juncoides complex" (Koyama, 1958, 1962, under Scirpus), which is comprised of perhaps 10 taxonomically difficult species of eastern Asia and the Pacific islands. The distinguishing characteristics of S. purshianus and S. smithii and the eastern Asian relatives with which they have been confused are summarized in Table 1.

\section{Delimitation of SChoENopleCtUS SECT. ACTAEOGETON}

The species of Schoenoplectus sect. Actaeogeton and section Supini were all included in Scirpus sect. Actaeogeton by Beetle (1942), Fernald (1942), and Koyama (1958, 1962). Raynal (1976) segregated Schoenoplectus sect. Supini from other sections based on the perianth bristles reduced or absent, and the ability to produce amphicarpic flowers in the basal leaf sheaths. Although species of Schoenoplectus sects. Actaeogeton and Supini are mostly very similar in both vegetative and sexual structures, our studies support their treatment as separate sections based mainly on the ability for amphicarpy and the usual presence of a node above the basal leaves in the latter (Smith \& Hayasaka, 2001). All plants of the North American species of these two sections can be distinguished by these characters (Smith \& Yatskievych, 1996), but some Old World species of Schoenoplectus sect. Supini, e.g., S. supinus (L.) Palla, lack a cauline leaf.

The following description of Schoenoplectus sect. Actaeogeton is based on about 300 specimens of the North American species and about 500 specimens of eastern Asian species as well as the descriptions and illustrations in Koyama $(1958,1962)$ and Ohwi (1965). The achene SEM micrographs provided by Oh and Ham (1998) show that the epidermal surface sculpturing of $S$. hotarui (Ohwi) Holub, S. lineolatus (Franchet \& Savatier) T. Koyama, S. triangulatus (Roxburgh) Soják, and S. wallichii (Nees) T. Koyama, all of which we include in section Actaeogeton (Smith \& Hayasaka, 2001), are very similar to each other, sharing longitudinally oriented, linear epidermal cells.

Schoenoplectus (Reichenbach) Palla sect. Actaeogeton (Reichenbach) J. Raynal, Adansonia 16: 130. 1976. Scirpus L. sect. Actaeogeton Reichenbach, Fl. Germ. Excurs.: 78. 1830. Schoenoplectus subg. Actaeogeton (Reichenbach) Oteng-Yeboah, Notes Roy. Bot. Gard. Edinburgh 33: 315. 1974. TYPE: Schoenoplectus mucronatus (L.) Palla.

Annuals or perennials, culms densely tufted, ca. 5-200 cm; rhizomes present or apparently absent, very short, hidden among culm bases and roots, or rhizomes long and horizontally creeping and culms single (in S. lineolatus). Culms cylindric or trigonous, ca. 1-200 cm long $\times 1-8 \mathrm{~mm}$ thick. Leaves all basal, $1 / 2$ of to rarely ca. equaling culm, ca. 2 leaves well developed; ventral band hyaline or membranous; ligules minute; blades from a mere mucro to ca. $8 \mathrm{~cm}$ long $\times 0.5-1 \mathrm{~mm}$ wide, cross section C-shaped or trigonous. Inflorescence of a single spikelet or usually capitate; spikelets 2 to 20 ; involucral bracts 1 to 2 , the proximal erect to divergent, channeled-subcylindric or trigonous, usually greatly exceeding the inflorescence. Floral scales elliptic to ovate; membranous with thicker midrib, often faintly many-nerved; margins ciliolate; apices entire, mucronate. Perianth present or absent, of 6 (or fewer) bristles that are retrorsely to spreading spinulose or rarely smooth. Styles bifid or trifid. Achenes dark brown to blackish when ripe, obovoid, lenticular to trigonous, abruptly short-beaked, prominently to obscurely rugose or nearly smooth at 10 to $20 \times$. Reported chromosome numbers $n=19,20,21,22,30,36,37$.

Habitats and distribution. Fresh-water wetlands, often emergent; worldwide, with the main center of diversity in eastern Asia.

This description is tentative pending further study of species, especially from Asia and Africa, where a taxonomic revision is needed. Fourteen species that we include in Schoenoplectus sect. Actaeogeton from North America and eastern Asia are listed in Smith and Hayasaka (2001), but it is possible that more species would be included after further study. Although S. lineolatus has long, hori- 
zontally creeping rhizomes in sharp contrast to the short, hidden rhizomes of all of the other species we include in Schoenoplectus sect. Actaeogeton, S. lineolatus closely resembles the other species in its leaves, floral scales, achene surfaces, and pericarp internal structure (Hayasaka, unpublished data). In addition, hybrids between $S$. lineolatus and both $S$. hotarui and $S$. triangulatus have been reported from Japan (Koyama, 1958; Hayasaka \& Ohashi, 2000).

Acknowledgments. The senior author especially thanks A. E. Schuyler for generously sharing his insights and unpublished research materials on Schoenoplectus, and A. Reznicek and M. Oldham for providing information and voucher specimens, especially from Canada. He also thanks the curators of the many herbaria that loaned specimens and accommodated his visits as listed in Smith (1995). We thank the directors and staff of the herbaria at the University of Wisconsin (WIS) and Tohoku University (TUS), and the Department of Biological Sciences of the University of Wisconsin-Whitewater for their essential logistical support and kind help in many ways. Two reviewers provided valuable critical comments, and Victoria Hollowell, scientific editor at Novon, provided valuable information, critical comments, and skillful editing. The junior author thanks Mitsuo Suzuki and Hiroyoshi Ohashi for their continuous help in many ways and warm encouragement since he began his work on Schoenoplectus in 1997, and the curators of A, BISH, BM, BRI, FLAS, GH, IBSC, KUN, L, NOU, P, SAPS, SING, SKK, SNU, TUS, TUSG, UPS, and URO for the loan of specimens or accommodating his visits.

\section{Literature Cited}

Beetle, A. A. 1942. Studies in the genus Scirpus L. V. Notes on the section Actaeogeton Reich. Amer. J. Bot. 29: 563-565.

Blondeau, M., C. Roy \& M. Garneau. 1996. Schoenoplectus purshianus. Une Cyperaceae nouvelle pour le Quebec. Nat. Canad. 120: 11-16.

Bruhl, J. J. 1995. Sedge genera of the world: Relationships and a new classification of the Cyperaceae. Austral. Syst. Bot. 8: 125-305.

Fassett, N. C. 1921. An estuarian variety of Scirpus smithii. Rhodora 23: 41-43.

Fernald, M. L. 1942. Transfers in Scirpus [sect.] Actaeogeton. Rhodora 44: 479-484.

Ferren, W. R., Jr. \& A. E. Schuyler. 1980. Intertidal vas- cular plants of river systems near Philadelphia. Proc. Acad. Nat. Sci. Philadelphia 123: 86-120.

Gleason, H. A. 1963. The New Britton and Brown Illustrated Flora of the Northeastern United States and Adjacent Canada, Vol. 1. Third printing, revised. Hafner, New York.

\& A. Cronquist. 1963. Manual of Vascular Plants of Northeastern United States and Adjacent Canada. D. Van Nostrand, Princeton, New Jersey.

Goetghebeur, P. \& D. A. Simpson. 1991. Critical notes on Actinoscirpus, Bolboschoenus, Isolepis, Phylloscirpus and Amphiscirpus (Cyperaceae). Kew Bull. 46: 168-178.

Hayasaka, E. \& H. Ohashi. 2000. New combinations in Japanese Schoenoplectus (Cyperaceae). J. Jap. Bot. 75: 223-225.

Koyama, T. 1958. Taxonomic study of the genus Scirpus Linné. J. Fac. Sci. Univ. Tokyo, sect. 3, Bot. 7: 271366.

- 1962. The genus Scirpus Linn. Some North American aphylloid species. Canad. J. Bot. 40: 913937.

1963. Nomenclatural remarks on the genus Scirpus. Phytologia 8: 457-458.

Merrill, E. D. \& S.-Y. Hu. 1949. Work and publications of Henry Muhlenberg, with special attention to unrecorded or incorrectly recorded binomials. Bartonia 25 : $1-66$.

Oh, Y. C. \& E. J. Ham. 1998. A taxonomic study on Scirpus Linné (Cyperaceae) of Korea. Korean J. Pl. Taxon. 28: 217-247.

Ohwi, J. 1965. Flora of Japan [in English]. Edited by F. G. Meyer \& E. H. Walker. Smithsonian Institution, Washington, D.C.

Oteng-Yeboah, A. A. 1974. Taxonomic studies in Cyperaceae-Cyperoideae. Notes Roy. Bot. Gard. Edinburgh 33: 311-316.

Raynal, J. 1976. Notes Cypérologiques: 26. Le genre Schoenoplectus II. L'amphicarpie et la sect. Supini. Adansonia, ser. 2, 16: 119-155.

Schuyler, A. E. 1972. Chromosome numbers of Scirpus purshianus and S. smithii. Rhodora 74: 398-402.

Smith, C. E., Jr. 1962. Henry Muhlenberg-Botanical pioneer. Proc. Amer. Philos. Soc. 106: 443-460.

Smith, S. G. 1995. New combinations in North American Schoenoplectus, Bolboschoenus, Isolepis, and Trichophorum (Cyperaceae). Novon 5: 97-102.

\& E. Hayasaka. 2001. Delineation of Schoenoplectus sect. Malacogeton (Cyperaceae), new combination, and distinctions of species. J. Jap. Bot. 76: 339343.

\& G. Yatskievych. 1996. Notes on the genus Scirpus s. lat. in Missouri. Rhodora 98: 168-179.

Strong, M. T. 1993. New combinations in Schoenoplectus (Cyperaceae). Novon 3: 202-203.

. 1994. Taxonomy of Scirpus, Trichophorum, and Schoenoplectus (Cyperaceae) in Virginia. Bartonia 58: 29-68.

Voss, E. G. 1972. Michigan Flora, Vol. 1. Cranbrook Institute of Science, Bloomfield Hills, Michigan.

Wilson, K. L. 1981. A synopsis of the genus Scirpus sens. lat. (Cyperaceae) in Australia. Telopea 2: 153-172. 